\title{
PEMIKIRAN QUTUB MUSHTHAFA SANU \\ TENTANG METODOLOGI IJTIHAD
}

\author{
Asep Arifin \\ UIN Sunan Gunung Djati Bandung \\ Email : aseparifin519@gmail.com
}

\begin{abstract}
Abstrak
Analisis pemikiran ini merupakan bagian dari tulisan yang disajikan oleh Abu Muhammad Amin dan A.D. Quthub Mushthafa Sanuw, Kualumpur, Malaysia. Tulisan ini berisi empat kajian pokok, yaitu: (1) analisis tentang konsep ijtihad yang ada dan kaitannya dengan realita kekinian, (2) kajian urgensitas model ijtihad yang dibutuhkan syari'at Islam pada setiap zaman dan tempat yang dihadapi, (3) deskripsi beberapa persoalan penting yang patut mendapat perhatian ijtihad dalam menghadapi tuntutan zaman, dan (4) penjelasan tentang dasar-dasar ijtihad metodologis (ijtihad manhaji) dalam menyelesaikan beberapa masalah sosial terutama dalam memproyeksikan dakwah Islam yang mengandung nilai-nilai Rabbani dan nilai-nilai insani pada tataran penyampaiannya (tanzîl).
\end{abstract}

\section{Kata Kunci: Mujtahid, Mukallid, ljtihad}

\section{Pendahuluan}

Tulisan ini merupakan analisis terhadap pemikiran pakar hukum Islam, Qutub Mushthafa Sanuw, tentang perlunya ijtihad kontemporer yang mampu menampakan prinsip-prinsip syari'at Islam, asas-asasnya, elastisitas hukum dan ajarannya, keluasan kandungan dan lafazhnya serta keampuhan sumber dan tujuannya dalam memenuhi segala kebutuhan pada setiap waktu dan ruang. Di samping itu, dikemukakan pula analisis mengenai dasar-dasar metodologi ijtihad sekitar beberapa masalah sosial yang berkembang dan memerlukan kajian kritis secara khusus.

Tulisan ini berisi empat kajian pokok, yaitu: (1) analisis tentang konsep ijtihad yang ada dan kaitannya dengan realita kekinian, (2) kajian urgensitas model ijtihad yang dibutuhkan syari'at Islam pada setiap zaman dan tempat yang dihadapi, (3) deskripsi beberapa persoalan penting yang patut mendapat perhatian ijtihad dalam menghadapi tuntutan zaman, dan (4) penjelasan tentang dasar-dasar ijtihad metodologis (ijtihad manhaji) dalam menyelesaikan beberapa masalah sosial terutama dalam memproyeksikan dakwah Islam yang mengandung nilai-nilai Rabbani dan nilai-nilai insani pada tataran penyampaiannya (tanzîl).

Keempat bahasan tersebut diperlukan untuk menjawab beberapa masalah pokok yang sudah lama dan tak pernah kunjung selesai. Pertama, masalah kekakuan dan kekhawatiran kalangan tertentu terhadap upaya-upaya pembaharuan dalam pemikiran hukum Islam (ijtihad), padahal di sisi lain ada tuntutan untuk membuktikan jati diri 
hukum Islam yang berwatak selalu relevan untuk setiap waktu dan ruang (shâlih li kulli zamân wa makân), serta kemampuannya memenuhi kebutuhan hidup manusia terutama dalam masalah-masalah baru, akibat perkembangan yang tak pernah henti dan perubahan yang silih berganti. Kedua, masalah psikologis yang terus mengungkung para penganut ajaran Islam bahwa para mujtahid terdahulu tidak lagi menyisakan lahan buat para mujtahid yang hidup belakangan sehingga inovasi dan reformasi ijtihad tidak mungkin dilakukan lagi, sebab setiap mujtahid dan konsep hukum yang lahir kemudian pada dasarnya kembali lagi kepada mujtahid yang telah ada, padahal realita menunjukkan bahwa segala nash atau lafazh hukum (ayat Al-Qur'an dan Hadits) telah berakhir turunnya, namun makna dan orientasi tujuannya tak pernah berhenti sejalan dengan dinamika persoalan-persoalan kehidupan sendiri, di mana masalah ini secara moral dan logis membutuhkan ijtihad yang konsisten dalam memahami makna-makna nash untuk menjawab segala tuntutan tersebut sehingga kemapanan dan karakter relevansitas agama Islam pada setiap ruang dan waktu benar-benar dapat terwujud dan teruji dalam kenyataan.

\section{ljtihad: Substansi dan Orientasinya.}

ljtihad yang relevan dengan kekinian dapat didefinisikan sebagai pengerahan maksimal dari kesanggupan dan kemampuan seseorang yang memiliki ilmu pengetahuan tertentu pada suatu masa untuk mengetahui kehendak hukum syara' tentang suatu kasus baru atau dalam menerapkan kehendak syara' tersebut. ${ }^{1}$

Konsep ijtihad yang proyektif dan prospektif ini mencakup tiga aspek penting: (1) model kesungguhan (keahlian) yang mesti dicurahkan, (2) kredibilitas sosok yang berijtihad, dan (3) tujuan yang akan dicapai dari model ijtihad tersebut.

Aspek pertama menuntut setiap mujtahid mencurahkan segala penguasaan ilmu dan keahliannya dalam mempraktekkan ilmu sekaligus, tidak parsial dalam dunia nyata sehingga upaya ini tidak terkesan asal-asalan, tetapi sebagai kesungguhan optimal dalam menjelaskan kehendak Tuhan semesta alam dan misi kepemimpinan Nabi saw dalam menyampaikan risalah, mengajar dan memberi fatwa hukum.

Aspek kedua menuntut pribadi mujtahid sebagai pribadi yang terkendali oleh batas-batas keilmuan yang memungkinkan dapat memahami kehendak wahyu llahi serta menjadi jaminan untuk mengimplentasikan-nya dalam kehidupan nyata. Di sini diperlukan berbagai disiplin ilmu lain yang dapat memperkaya ilmunya dan mempertajam keahliannya dalam menghadapi peristiwa-peristiwa hukum dalam ruang dan waktu yang dihadapinya.

Aspek ketiga, yaitu sasaran dan tujuan ijtihad, menuntut bahwa seluruh potensi ijtihad, baik yang bersifat nalar maupun teknis diarahkan untuk sampai kepada kehendak

${ }^{1}$ Qutub al-Mushthafa Sanu, Al-ljtihâd wa Mustajiddat al'-Ashr, makalah pada Seminar Internasional (Libiya: World Islamic Call Society, 27-30 Oktober 2008), hlm. 1-7. 
Ilahi tentang status hukum suatu peristiwa. Aspek terakhir ini mengilhami perlunya pembagian ijtihad ke dalam ijtihad teoritis dan ijtihad praktis yang dinamakan sebagai ijtihad tathbîqî atau ijtihad tanzîlî.

\section{Kriteria ijtihad masa kini}

Untuk memelihara tradisi ijtihad dan fatwa agar tetap dilakukan oleh ahlinya maka perlu ditetapkan beberapa kriteria yang prinsipil. Pertama yaitu menguasai bahasa Al-Qur'an (ilmu nahw, sharaf dan balaghah). Syarat ini diperlukan agar orang yang hendak melakukan ijtihad atau berfatwa harus menguasai dasar-dasar dan prinsipprinsip umum bahasa Arab mengingat teks Al-Qur'an dan Sunnah berbentuk bahasa Arab.

Kriteria yang kedua adalah memahami kriteria hadits. Orang yang berijtihad dituntut mampu mengetahui kualitas (nilai) suatu hadits antara yang sahîh, hasan, dha'îf, maudhû' dan lainnya, serta dasar-dasar penilaian sahîh, dha'îf, keadilan dan ketidakadilan, terutama kuantitas hadits antara hadits mutawâtir dan hadits ahad sebagaimana yang ditegaskan oleh Al-Syaukani. ${ }^{3}$

Kriteria ketiga yaitu memahami ilmu ushul fiqh. Ilmu ini diperlukan karena berbicara tentang kaidah-kaidah dan asas-asas yang dibutuhkan dalam berijtihad. Al-Razy menganggap ilmu ini sebagai ilmu terpenting dalam berijtihad dan berfatwa. ${ }^{4}$

Kriteria keempat adalah diwajibkan orang tersebut memahami ilmu ushuluddin. Ilmu ini penting untuk membekali para mujtahid tentang dasar-dasar dan kaidah-kaidah aqliyah dan naqliyah sehingga mereka mampu mempertahankan akidah agamanya dari berbagai tantangan secara argumentatif, baik yang datang dari dalam umat Islam maupun dari umat lainnya. Memahami pokok-pokok ajaran agama lainpun menjadi keniscayaan bagi yang menekuni dunia fatwa dan ijtihad.

Kriteria selanjutnya yaitu memahami maqashid al-syarîah. Memahami hal ini dipandang sebagai pengaman dan alat penjamin bagi yang berijtihad agar dirinya tidak tergelincir dalam kesesatan dan kesalahan memahami nash-nash (Al-Qur'an dan Sunnah). Siapa saja yang tidak memahami ilmu ini, ia hanya akan memegang dalil-dalil parsial dan mengabaikan makna universal dan ruh syari'atnya. Untuk hal ini, sangat bijak bila memegang pernyataan Al-Syatabi bahwa mengetahui maqâshid al-syarîah secara benar akan mengantarkan kita kepada apa yang sebenarnya dikehendaki Allah, Tuhan semesta alam. Orang yang memahami maqâshid al-syarî'ah adalah orang yang dapat menempati posisi pengganti (khalifah) Rasul Saw di dalam mengajar, berfatwa dan menetapkan hukum sesuai dengan yang diajarkan Allah. ${ }^{5}$

\footnotetext{
${ }^{2}$ Ibid, hlm. 8.

${ }^{3}$ Al-Syaukani, Irsyad al-Fuhul (Mesir: Dar al-Kutub, 1992), juz 2, cet. 1, hlm. 300.

${ }^{4}$ Al-Razy, Al-Mahshul fîllmi Al-Ushul (Beirut: Muassasah al-Risalah, 1992), cet. Kedua.

${ }^{5}$ Asy-Syatibi, Abu Ishaq. Tanpa Tahun. Al-Muwâfaqât fî Ushûl al-Ahkâm. Ta'lîq [Komentar] oleh Muhammad Al-Hidhr Husain. Juz IV., Beirut: Darul Fikr. hlm. 107
} 
Adapun kriteria lainnya yaitu memahami ilmu-ilmu aliran pemikiran dalam Islam yang berimplikasi pada ilmu tentang perbedaan pendapat (ilmu al-khilaf). Dengan memahami ilmu ini, seorang mujtahid dimungkinkan akan mampu menguasai perbedaan ijtihad dari para sahabat, tabi'in, tabi' tabi'in dan para imam mujtahid ternama, khususnya tradisi ijtihad yang masih ada sampai masa kini. Dalam hal ini, Syekh Muhammad alKhadar al-Husain mengatakan bahwa mengetahui berbagai aliran pemikiran dan studi hukum yang bermuara pada prinsip-prinsipnya merupakan langkah cepat bagi seorang ulama dalam berijtihad. Jika hal ini tidak dikuasai, maka tenaga dan waktu akan sia-sia terbuang dan fatwapun akan lebih banyak yang tidak tepat. ${ }^{6}$

Kriteria ketujuh bagi orang yang berijtihad yaitu mengetahui kaidah-kaidah induk fiqh, minimal kaidah-kaidah fiqhiyyah kulliyah yang enam dan anak cabangnya. Dengan mengetahui kaidah-kaidah ini seorang mujtahid tidak perlu menghabiskan waktu cukup lama untuk kembali kepada kitab-kitab fiqh klasik, sebab kaidah-kaidah fiqhiyyah ini merupakan intisari pemikiran hukum yang dapat diandalkan dalam merumuskum hukum syara' secara konseptual bagi masalah-masalah kontemporer dan setiap perubahan.

Adapun kriteri terakhir, orang tersebut diharuskan untuk mengetahui prinsipprinsip ilmu modern. Dengan mengatahui ilmu modern, paradigma dan metodemetodenya, seorang mujtahid dimungkinkan akan mampu memahami realitas yang dihadapi manusia, khususnya masalah mental, sosial, politik, ekonomi, dan hukum yang mempengaruhi manusia, baik secara pasif maupun aktif. Semua ilmu ini bersumber dari manusia (humanisme) bahkan manusia sendiri menjadi obyeknya. ${ }^{7}$ Dengan demikian, untuk zaman sekarang memahami hal ini diituntut oleh agama sendiri, bahkan menjadi keharusan indvidual (wajib ain) bagi yang berijtihad dan menjelaskan kehendak Tuhan agar diperoleh kesesuaian antara hukum dengan ruang atau waktu yang dialami manusia. Seorang mujtahid, bila tak menguasai ilmu sosilogi atau ilmu-ilmu lainnya, maka ia akan kaku dan akan menyia-nyiakan cara mengetahui kehendak Tuhan secara kontektual dengan realita kehidupan manusia; akal seorang muslim tak akan mampu menjelajah belahan bumi, tak akan mampu memahami bangkit atau jatuhnya suatu bangsa serta perubahan-perubahan sosial lainnya. ${ }^{8}$

Kedelapan ilmu tersebut merupakan persyaratan penting yang memungkinkan seorang mujtahid moderen dapat mengeluarkan pemikiran hukum yang tepat dan relevan dengan perubahan politik, sosial, dan budaya.

\footnotetext{
${ }^{6}$ Muhammad al-Hadhar al-Husain, Al-Syari'at al-Islamiyyah shâlih likulli zamân wa makân (T.Tp:t.p, 1971), hlm. 11.

${ }^{7}$ Ibnu al-Qayyim Al-Jauziyah (Pent. Kathur Suhardi), Zadul-Maád Bekal Menuju Akhirat, Jakarta : Pustaka Azam, hlm. 102.

${ }^{8}$ Umar Ubaid Hasanah, Tammulat fî al-waqi' al-Islamy (Beirut: Al-Maktab Al-Islami, 1990), cet. Pertama, hlm.21.
} 


\section{Syari'at Islam Perlu ljtihad yang Berkelanjutan: Hukum Syara' Antara yang Paten dan Fleksibel.}

Telah menjadi statemen penting bahwa syari'at Islam adalah ketentuan Tuhan yang bersifat abadi bagi setiap masa dan tempat. Sering pula dikatakan bahwa setiap hukum yang ditetapkan senantiasa relevan menghadapi situasi dan kondisi. Pemikiran dan penalaran pertama menyebutkan bahwa segala hukumnya tersimpan di dalam teks dan lafaz-lafaz yang memiliki tingkat kejelasan makna yang berbeda sehingga memerlukan usaha optimal untuk menjelaskannya dan memahaminya dengan benar dan baik, sebagai suatu tuntutan yang harus dipenuhi maupun larangan yang mesti dihindari.

Mengingat adanya perbedaan teks hukum, maka hukumpun ada yang bernilai pasti (qath'i) dan yang bernilai nisbi (zhanni). Dari pemahaman semacam ini, hukum dapat dibedakan ke dalam dua sifat; (1) hukum yang bersifat abadi dan tidak mengalami perubahan akibat situasi, kondisi dan keadaan lingkungan, dan (2) hukum yang bersifat dinamis seiring dengan tuntutan perubahan situasi dan kondisi yang mempengaruhi pembentukannya.

Klasifikasi sifat hukum seperti itu telah mentradisi di kalangan masyarakat Islam sepanjang zaman, padahal secara ilmiah (ontologis), hukum itu sendiri tidak membuktikan adanya perubahan, pergantian dan perkembangan. Karena itu, yang berubah itu adalah pemahaman hukum itu sendiri. Alasanya, karena hukum menurut tradisi ahli metodologi hukum Islam (ushuliyyin) didefinisikan sebagai khitab al-syar'i (pernyataan Allah pembuat syara') yang berkenaan dengan perbuatan mukallaf, baik yang bersifat tuntutan maupun pilihan. Pernyataan Tuhan ini bersifat abadi dan jauh dari perubahan, pergantian dan perkembangan dalam situasi apapun. Tetapi pemahaman adanya perubahan hukum itu secara lebih khusus berkaitan dengan lafazh yang mengandung beberapa asumsi makna (dilalah zhanniyah). Dengan demikian, pernyataan Allah (khitabullah) sendiri sebenarnya tidak mengalami perubahan. Alhasil, pembagian hukum ke dalam hukum yang bersifat paten dan bersifat berubah merupakan pembagian yang bersifat konotatif, bukan substansial. Pemahaman seperti ini perlu ditelaah kembali agar terhindar dari pemikiran Islam kontemporer yang telah mengabaikan makna teks yang bersifat pasti dan yang bersifat nisbi. Karena itu, di sini penting dikemukakan stratifikasi teks hukum tersebut agar sampai pada konsep metodologis yang tepat. Stratifikasi teks hukum ada empat sifat. Teks yang pertama yaitu teks hukum yang bersifat pasti sumbernya dan jelas arah maknanya. Yakni, teks hukumnya diperoleh berdasarkan data empiris yang memiliki kebenaran umum (tawatur) serta mengandung arah lafaz yang bermakna tegas, seperti teks-teks tentang rukun Islam, rukun iman, rukun ihsan, ketentuan rinci hukum fara'id (ketentuan pembagian harta pusaka), hukum hudud, qishas serta hukum-hukum agama yang telah diketahui umum kebenarannya.

Sifat yang kedua yaitu teks hukum yang bersifat tidak pasti sumbernya dan tidak jelas arah maknanya. Yakni, teks hukum yang sampai ke hadapan kita diperoleh secara 
perorangan (khabar ahad), yang menunjukkan makna hukum tidak pasti (dilalah zhanniyyah) karena memuat beberapa makna dalam satu situasi. Teks-teks hukum yang lentur ini menjadi wilayah kajian ijtihad yang menuntut para mujtahid agar mampu menempuh sejumlah sejumlah metode ijtihad, baik dalam menetapkan validitas sumber lahirnya suatu dalil sehingga melahirkan nilai sah (tashih), lemah (tad'if), diterima (qabul) dan ditolak (radd), maupun menentukan makna yang paling tepat sehingga melahirkan perbedaan konsep hukum yang dikehendaki syara' dalam kaitannya dengan kenyataan. Karena itu, pemahaman sekitar teks-teks hukum merupakan pemahaman yang berbeda dan terus berkembang, yang tak patut dijadikan sebagai pemahaman yang ekslusif, apalagi disakralkan, oleh suatu generasi manusia, tetapi harus tetap menjadi wilayah yang terbuka untuk menerima pembaharuan-pembaharuan pemikiran hukum Islam.

Jenis teks yang ketiga yaitu teks hukum yang bersifat pasti sumbernya namun tidak tegas maknanya. Yakni, dilihat dari asal datangnya suatu dalil, teks hukum bernilai pasti karena berasal dari Al-Our'an dan Sunnah mutawatir, tetapi makna-maknanya mengandung beberapa pengertian.

Jenis teks yang keempat yaitu teks hukum yang bersifat zhani sumber datangnya dan berifat pasti kandungan maknanya. Yakni, teks-teks hukum yang bersumber dari hadits-hadits ahad namun mengandung pengertian hukum yang pasti kerena hanya memiliki satu makna atau satu pengertian sehingga tidak ada kemungkinan untuk dipahami lebih jauh. Pemahaman hukum yang bersumber dari sifat teks semacam ini dapat berubah menurut metode yang digunakan oleh mujtahid sendiri walau pada asalnya teks hukum tersebut mengandung makna yang sudah pasti, sebab suatu pemikiran tak ada jaminan dapat menolak terhadap tuntutan, perkembangan dan pergantian. Umpamanya, suatu teks hukum bisa jadi dinilai oleh seorang mujtahid tidak sah dan tidak dapat diterima sehingga tidak punya kepastian hukum. Namun bagi seseorang yang terus menelitinya bisa jadi sampai pada kesimpulan dan penilaian yang berbeda tentang teks hukum tersebut. Yang mudah, misalnya, dapat kita jumpai suatu hadits dinilai sahîh oleh seorang imam hadits dan dinilai dha'îf oleh imam lainnya, maka bagi yang menilai sahîh, maka ia akan memegang teguh makna dan hukum yang terkandung di dalamnya, sementara bagi yang menilai dha'îf tidak demikian. Karena itu, teks semacam ini termasuk wilayah kajian pembaharuan pemikiran hukum sepanjang zaman.

Demikianlah macam-macam teks hukum yang melahirkan sejumlah karakter hukum syara'. Pemahaman teks hukum yang bersifat qath'iyyah al-tsubut wa al-dilalah melahirkan nilai hukum yang bersifat pasti dan abadi, sedangkan teks-teks hukum lainnya melahirkan pemahaman hukum yang berubah seiring dengan tuntutan situasi, kondisi serta realita yang dihadapi. Atas dasar ini dapat kita katakan bahwa karakter umum dari hukum yang dihasilkan teks-teks hukum adalah bersifat elastis dan luas untuk setiap situasi dan kondisi yang ada sehingga ijtihad menjadi sesuatu yang sangat penting 
sepanjang zaman, yang tak boleh diragukan lagi sebagai sesuatu yang harus dan dibutuhkan. Tuntutan ini merupakan bukti dari bagian sejarah peradaban umat, sebab umat yang tidak melakukan reformasi pemikirannya akan menerima keterasingan, tak kuasa bersaing serta melupakan kewajiban-kewajibannya. Tidak ada bukti nyata bagi kejayaan umat ini selain buah pemikirannya yang dinamis (fikr ijtihadi) dengan memegang teguh pada metodologi hukum dan tujuan hukum sendiri serta akibatakibatnya dalam mencermati setiap peristiwa hukum.

\section{Beberapa Metode ljtihad yang Mampu Mengatasi Tuntutan Zaman}

Apabila hukum Islam harus lahir dari teks hukum yang bersifat qathi saja, baik tsubut maupun dilalahnya, maka dipastikan banyak peristiwa hukum yang tidak akan memiliki status hukumnya, seperti segala peristiwa yang dialami umat Islam setelah wafat Rasulullah saw; masalah politik, ekonomi, dan sosial, yang telah memaksa sejumlah para pemikir hukum untuk melakukan pembaharuan dan menemukan metode hukum yang mampu menjawab persoalan-persoalan aktual tersebut. Di antara metodemetode yang telah teruji keampuhannya sepanjang masa di kalangan ahli ushul fiqh adalah metode qiyas, istihsan, istihlah, sadd al-dzari'ah, istishhab dan lainnya.

Walau berbeda dengan pandangan Al-Ghazali yang menilai ragam metode ijtihad tersebut sebagai sumber-sumber hukum yang tidak penting, namun kami menilai sebaliknya, sebab metode qiyas sudah teruji dan mentradisi di sebagian besar madzhabmadzhab hukum Islam dan begitu pula dengan metode lainnya walau tidak lepas dari diskursus dan kritik akademik. Semua metode ini layak diterima dan digunakan sesuai dengan kebutuhan dan masalah yang dihadapi; tak jadi masalah, apakah suatu peristiwa hukum itu ada yang dapat diselesaikan dengan metode qiyas jika memang sifat masalahnya ada kesamaan ilat hukum (unsur penting dalam aplikasi qiyas) atau metode lainnya menurut karakter dan pertimbangan aspek hukum yang ada.

Atas pemikiran tersebut, maka bagi yang memenuhi kriteria ijtihad sangat tepat baginya bila tidak mengkhususkan diri dengan satu metode, misalnya metode qiyas saja, sebab tidak semua peristiwa hukum yang baru memiliki illat yang sama, dan karena itu bisa diselesaikan dengan metode lainnya. Di sinilah pentingnya pemikiran metodologis (ijtihad manhaji) untuk ditumbuhkembangkan dalam mengatasi setiap persoalan yang baru. ljtihad manhaji ini berpijak pada tiga dasar pokok; prinsip-prinsip umum syarîah (ushul 'ammah); tujuan hukum (maqâshid), dan memperhatikan akibat-akibat hukum (ma'alat).

\section{Memegang prinsip umum syarî'ah}

Apabila pernyataan bahwa syari'at Islam senantiasa relevan untuk setiap ruang dan waktu dan bahwa teks-teks hukumnya berwatak elatis serta luas telah menjadi konsensus para ahli hukum Islam, maka hal ini menuntut bahwa setiap peristiwa hukum yang baru mesti terjamin dalam watak teksnya yang elastis, umum serta kaidah-kaidah 
kulliyah sehingga sampai pada tujuan yang dihendaki syara'. Singkatnya, menjelaskan hukum syara' untuk kasus-kasus baru sebaiknya berdasarkan prinsip-prinsip dan kaidahkaidah umum yang disimpulkan para ulama dari teks Al-Our'an dan Sunnah Nabi Saw yang bersifat umum, misalnya, kaidah "al-ashlu fy al-asyya al-ibahah "(hukum dasar segala sesuatu adalah boleh), "al-ashlu fy al-mu'amalat al-ibahah "(hukum asal pada setiap muamalah adalah boleh), "al-aslu fy al-ma'kulat wa al-masyrubat al-ibahah "(hukum asal dalam setiap makanan dan minuman adalah boleh), dan kaidah-kaidah umum lainnya. Penterapan kaidah-kaidah ini bisa menjadi suatu keharusan bagi seorang mujtahid manakala dirinya kesulitan dalam menjelaskan kasus hukum baru secara tekstual.

Konsekuensi jauh dari pemikiran metodologis di atas, maka tidaklah tepat bila memposisikan status peristiwa-peristiwa kontemporer dengan status hukum yang sudah lama, baik dalam masalah perikatan, muamalah, maupun kegiatan-kegiatan ekonomi lainnya. Bahkan tak logis dan tidak etis bila semua kasus baru sekitar kegiatan kerjasama (syarikat) di zaman moderen harus selalu ditetapkan dengan metode qiyas atas praktek kerjasama perekonomian yang telah lama ada, sebab peristiwa yang lamapun bukan berdasarkan teks hukum langsung dari Al-Qur'an atau hadits tetapi berdasarkan makna umum kandungannya.

\section{Mengutamakan tujuan hukum syara' (maqâshid al-syar'i)}

Apabila nash Al-Qur'an dan Sunnah yang bersifat umum dijadikan pemutus (hakim) dalam memecahkan masalah-masalah aktual secara metodologis, tematis dan sistemik, maka di samping itu masih ada pertimbangan hukum lainnya yang tak kalah pentingnya yang mampu menampakkan makna dan sasaran nash syara' yang bersifat umum yang terkandung dalam berbagai prinsip hukum itu sendiri. Pertimbangan hukum ini dikenal dengan maqâshid syara', baik yang tujuan bersifat umum maupun khusus. ${ }^{9}$ Hal ini mengisyaratkan bahwa seorang mujtahid sepantasnya memahami benar tentang makna dan sasaran hukum yang dinilai sebagai rahasia tasyri' yang bersifat umum dan adaptif dalam menghadapi setiap persoalan baru (politik, sosial atau lainnya) sehingga ia dapat menetapkan dan membedakan makna hukum yang bersifat abadi dengan yang bersifat dinamis dan elastis.

Orang yang memperhatikan sejumlah nash hukum yang sifatnya umum untuk masalah-masalah baru, ia akan menemukan adanya nash hukum yang mengandung makna yang sangat jelas, abadi dan bertujuan, serta rahasia-rahasia besar yang konstan tak berubah karena dimensi ruang, waktu dan faktor lain.

Mempertimbangkan tujuan hukum sebagai prioritas sangat penting dalam mengarahkan ragam pendapat pada sasaran yang tepat sehingga tidak terjadi kontra-

\footnotetext{
${ }^{9}$ Imam Alal al-Fasy mendefinisikannya maqashid al-syari'ah dalam pengertian sasaran dan rahasia hukum yang ditetapkan Allah (Beirut: Dar al-Gharbi, 1993), hlm. 7 dst.
} 
diksi. Karena itu, tujuan hukum ini sifatnya permanen, tak mengalami perubahan atau pergantian, sementara pemikiran hukum sendiri yang disebut ijtihad hanya sebagai instrumen (wasilah) untuk mencapai tujuan itu. Apabila segala ijtihad tak mampu mengantarkan kepada tujuan yang dimaksud, maka harus beralih kepada pemikiran lain yang lebih terarah.

Menempatkan maqâshid syara' sebagai suatu orientasi (taujîh), penegasan (taqrîr) dan prioritas (tarjîh) berarti suatu jaminan mengetahui maksud Pembuat hukum (Allah sebagai Syari') ke dalam bingkai cakrawala pemikiran lama atau baru yang sangat luas dan terarah untuk merealisir tujuan tersebut. Karena itu, bentuk pemikiran dan ijtihad yang mampu membuktikan tujuan hukum wajib diprioritaskan ketimbang yang lainnya. Cara penempatan seperti itu merupakan fungsi penting dari ijtihad metodologis dan proporsional, sebab segala macam nash syara serta tujuannya merupakan satu kesatuan yang utuh dan sempurna.

Dengan menempatkan tujuan hukum sebagai penetapan berarti akan menampakkan makna yang unggul dan mudah dijadikan sandaran dalam memecahkan persoalan-persoalan baru, karena teks hukum terbatas jumlahnya dan tidak demikian dengan makna-maknanya. Sangat tak logis bila suatu makna tekstual diabadikan, apalagi disakralkan, untuk sembarang tempat dan waktu.

Sedangkan menjadikan tujuan hukum sebagai skala prioritas berarti menjadikannya sebagai neraca dalam menimbang pemikiran yang benar, pandangan yang tepat serta arah ijtihad. Suatu pengertian apapun tak dapat dipertimbangkan bila tak mampu membentuk berbagai prinsip dan konsep hukum, dan prinsip serta konsep hukum inipun hanya sebagai instrumen yang dapat berubah dan berganti, berbeda dengan tujuan seperti telah dijelaskan. Sementara itu, dengan menjadikan tujuan hukum sebagai faktor penegas akan menjadikannya sebagai barometer untuk memastikan suatu makna atau prinsip hukum dalam ruang dan waktu tertentu.

\section{Mempertimbangkan akibat perbuatan dalam menetapkan hukum bagi kasus-kasus baru.}

Bertitik tolak dari teori yang sempurna tentang tujuan hukum sehingga menjadi karakter utama bagi tasyri' Islam dan prinsip-prinsipnya, maka mempertimbangkan akibat-akibat yang akan terjadi dari suatu perbuatan merupakan jaminan kuat untuk menerapkan pemikiran dalam konteks proses turunnya suatu teks hukum (alam tanzil), sebab pemikiran dan pandangan hukum yang realistis akan menampakkan bentuk konsep yang elastis sehingga akan terjadi keseimbangan antara alam proses pewahyuan (alam tanzili) dengan alam terapan (alam tathbiqi). Betapa pentingnya mempertimbangkan segi ini telah diakui oleh Imam Asy-Syatibi sebagaimana pernyataannya:

"Memperhatikan akibat suatu merbuatan merupakan sesuatu yang sangat dipertimbangkan dan dituju oleh syara', sebab seorang mujtahid tak akan menetapkan bahwa suatu perbuatan harus dilakukan atau sebaliknya kecuali setelah mempertimbangkan 
akibat-akibatnya yang berupa kemaslahatan atau kemafsadatan.., Memperhatikan akibatakibat perbuatan merupakan lahan bagi seorang mujtahid dan sulit diperoleh namun akan terasa senang bila menggapainya sejalan dengan tujuan hukum syara' (maqâshid alsyarî'ah) ". ${ }^{10}$

Dengan demikian, antara teori pemikiran hukum dengan penterapannya dalam kehidupan nyata merupakan suatu sistem hukum yang sempurna (saling melengkapi) dalam pandangan Islami kekinian.

\section{Dasar-Dasar ljtihad Manhaji dalam Beberapa Kasus Muslim Minoritas}

Terjadinya arus globalisasi tak dapat dipungkiri dan dihindari telah berimplikasi pada asimilasi tradisi dan kebudayaan antar bangsa dengan segala perbedaan agama dan kepercayaannya. Dunia yang luas kini terasa kecil dan tak ada lahan bagi pemikiran yang sempit; agama tak lagi menjadi pertimbangan fanatis bahkan terasa semakin terpenjara bagi peradaban yang otoritet dan tirani. Hal inilah yang mendorong perlunya pemikiran ulang terhadap nilai-nilai positif hasil ijtihad terdahulu untuk diketahui prinsipprinsipnya yang dapat diterima secara nurani terutama dalam memelihara peradaban Islam jangan sampai runtuh; manakah nilai-nilai peradaban yang abadi dan tak mengalami perubahan serta pergantian, dan manakah nilai-nilai peradaban yang dapat berubah dan berganti dalam ruang dan waktu yang mempengaruhinya.

Salah satu masalah penting zaman kini adalah berijtihad tentang teori pemenang kekuasaan (ghalib) terhadap yang dikuasainya (maghlub) dan teori pihak yang diikuti (matbu) bagi pengikutnya (tabi), bahkan tak asing bahwa kemenangan kebudayaan dan peradaban punya pengaruh yang jelas terhadap ijtihad dan pemikiran hukum Islam terutama dalam menyelamatkan peradaban umat yang mengalami kekalahan dalam banyak hal. Karena itu, untuk mengatasinya diperlukan pemikiran yang serius dan mental agama yang kuat serta kemaslahatan yang aktual dalam meletakkan dasar-dasar berijtihad yang benar dan tepat dalam memecahkan persoalan yang baru dan terus berkembang. Dasar-dasar berijtihad tersebut, antara lain; (1) memperkuat metode aldzarâ'i (instrumen) dalam membuka (fathu al-dzari'ah) atau menutup sesuatu (sadd aldzari'ah), (2) menggunakan kaidah-kaidah kulliyah dari fiqh dan ushul fiqh, serta (3) mempertimbangkan tujuan hukum dan akibat perbuatan (itidad al-maqâshid wa alma'alat).

\section{Memperkuat Metode al-Dzara'i.}

Al-dzarâ'i, menurut tradisi ulama bahasa dan ulama ushul fiqh, sama artinya dengan al-wasa'il, yaitu perantara atau instrumen yang dapat mengantarkan kepada sesuatu yang bernilai haram, wajib, mandub, makruh atau mubah. Dalam ungkapan lain, al-dzarâ'i adalah al-wasa'il yang dapat menimbulkan sesuatu yang haram bila berkenaan

${ }^{10}$ Asy-Syatibi, Abu Ishaq, Al-Muwâfaqât fî Ushûl al-Ahkâm. Ta'lîq [Komentar] oleh Muhammad AlHidhr Husain. Juz IV., Beirut: Darul Fikr. hlm. 552. 
dengan sesuatu yang diharamkan atau yang dapat mengakibatkan yang halal bila berkenaan dengan sesuatu yang dihalalkan dan begitu seterusnya. Akan tetapi dari kajian sejumlah literatur tentang ushul fiqh klasik dan moderen, metode al-dzarâ'i atau al-wasa'il lebih banyak diorientasikan dalam hal-hal yang mengakibatkan atau menimbulkan sesuatu yang diharamkan, sedangkan al-wasa'il lainnya, seperti hal-hal yang mendukung sesuatu yang wajib, yang sunnat, yang mubah dan lainnya, sama sekali kurang perhatian. Hal ini nampak dalam tema-tema yang dibuat ulama sendiri, seperti al-Bajy dalam kitabnya, al-Isyarat, mendefinisikan al-dzarâ'i dengan pernyataan,"...almas'alah allati zhahiruha al-ibahah wa yatawashshalu biha ila fi'li al-mahdzur "(masalah yang kelihatannya dibolehkan namun akhirnya dapat menjadi sesuatu yang dilarang). Di dalam kitab, al-hudud, al-Bajy mendefinisikan al-dzarâ'i dalam pernyataan"...ma yatawashshalu bihi ila mahdhur al-uqud min ibram al'aqad aw hillihi "(segala hal yang dapat menimbulkan akad-akad yang dilarang; dibebaskan atau dihalalkan). Sementara Qadli Abdul Wahab al-Bagdadi mendefinikan al-dzarâ'i sebagai sesuatu yang zhahirnya dibolehkan namun menjad dilarang karena diduga kuat mengarah ke suatu yang dilarang itu. ${ }^{11}$

Berdasarkan keterangan tersebut, maka al-dzarâ'i selalu disertai dengan kata sandingannya, seperti sadd al-dzari'ah (mencegah atau menghalangi pelantara /instrumen) sehingga terkenal dengan istilah kaidah sadd al-dzari'ah. Sedangkan kaidah fathu al-dzari'ah (membuka pelantara) lebih banyak diabaikan dalam kajian ilmiah, padahal jauh-jauh sebelumnya telah diperingatkan oleh Imam al-Qurafi dalam karyanya, Al-Faruq: "Ketahuilah, al-dzari'ah, sebagaimana wajib ditutup (saddu al-dzari'ah), maka membukakannya wajib pula (fathu al-dzari'ah), bahkan disunnatkan, dimakruhkan dan dibolehkan, sebab dzari'ah sendiri berarti sesuatu yang menjadi wasilah atau perantara; suatu wasilah yang menyebabkan keharaman, maka haram pula hukumnhya, dan wasilah yang wajib, maka wajib pula hukumnya, seperti berusaha pergi untuk shalat Jum'at atau ibadah haji. Dengan demikian, sumber hukum itu ada dua, yakni; maksudmaksud (maqâshid) yang terdiri dari kemaslahatan dan kemafsadatan, dan wasilahwasilah, yakni, segala cara atau jalan yang mengantarkan kepada tujuan tersebut sehingga memiliki nilai hukum yang sama dengan hukum tujuannya sekalipun berada di bawah hukum tujuannya. Tinggi atau rendahnya hukum wasail tergantung kepada tinggi atau rendahnya tujuan hukum. Salah satu nilai wasail terbaik adalah berbuat kebaikan itu sendiri, sebagaimana firman Allah, surat Al-Taubah:120.

"Tidaklah sepatutnya bagi penduduk Madinah dan orang-orang Arab Badwi yang berdiam di sekitar mereka, tidak turut menyertai Rasulullah (berperang) dan tidak patut (pula) bagi mereka lebih mencintai diri mereka daripada mencintai diri rasul. yang demikian itu ialah karena mereka tidak ditimpa kehausan, kepayahan dan kelaparan pada jalan Allah, dan tidak (pula) menginjak suatu tempat yang membangkitkan amarah orang-orang

${ }^{11}$ Qadli Abdul Wahab al-Bagdadi, Al-Isyraf ala masa'il al-Khilaf, juz. 1, hlm. 275. 
kafir, dan tidak menimpakan sesuatu bencana kepada musuh, melainkan dituliskanlah bagi mereka dengan yang demikian itu suatu amal saleh. Sesungguhnya Allah tidak menyianyiakan pahala orang-orang yang berbuat baik".

Allah menghargai mereka lantaran kepayahan dan kelaparan, padahal dua hal ini bukan hasil perbuatan mereka tetapi karena menjadi pelantara menuju jihad sehingga menjadi wasilah untuk memuliakan agama dan melindungi muslimin sehingga mempersiapkan segala sesuatu yang berhubungan dengan jihad merupakan wasilah bagi wasilah itu sendiri.

Berbeda dengan pandangan al-Qurafi, madzhab Malikiyah dan Hanabilah yang menganggap pentingnya al-dzarâ'i ini sehingga dapat menjadi dasar hukum (hujjah), maka para ulama dari kalangan madzhab Hanafiyah, Syafi'iyah dan Zhahiriyah tidak menjadikannya sebagai hujjah.

Madzhab Malikiyah dan Hanabilah menganggap al-dzarâ'i sebagai dalil hukum terpenting dari sekian dalil hukum yang belum disepakati dalam menjelaskan hukum syara untuk kasus-kasus baru tentang muamalah, munakahat, uqubat dan lainnya. Menurut Ibnu al-Qayyim, sesungguhnya sadd al-dzari'ah mengisi seperempat agama. ${ }^{12}$

Perbedaan pendapat sekitar dzara'i ini hanya bersifat situasional, kapan sesuatu pelantara (waslah) itu boleh dibukan (fathu al-dzari'ah) dan kapan boleh ditutup (sadd aldzari'ah), sebab secara substansi kedua langkah ini sama-sama diperintahkan agama. Terkait dengan hal ini, Al-Qurafi menegaskan bahwa bagian dari dzara'i ada yang diakui ijma' seperti larangan menggali sumur di tengah jalan kaum muslimin, mencamprkan racun ke dalam makanan mereka, dan ada pula yang tidak diterima secara ijma', seperti menanam anggur karena dikhawatirkan jadi bahan khamar, serta ada pula yang masih diperselisihkan seperti jual beli berjangka waktunya (Malikiyah tak mentelorir masalah ini). Penilaian yang sama disampaikan pula oleh al-Qurthubi.

Al-Syathibi di dalam Al-Muwafaqat, membagi al-dzarâ'i ke dalam empat macam. Pertama, sesuatu yang dipastikan dapat menimbulkan mafsadat, seperti menggali/ membuat sumur di belakang pintu/jalan masuk rumah yang gelap sehingga orang akan terjerumus, dan hal ini dilarang secara tegas. Kedua, sesuatu yang terkadang dapat menimbulkan mafsadat, seperti menggali sumur pada tempat yang tak galib dilalui orang. Hal ini dibolehkan. Ketiga, sesuatu yang biasanya lebih sering menimbulkan mafsadat, seperti menjual senjata kepada ahli perang atau menjual anggur kepada pembuat khamar atau pemabuk. Maka hal ini wajib ditutup, tak boleh diberi jalan. Keempat, sesuatu yang umumnya menimbulkan mafsadat, seperti kegiatan jual beli berjangka waktu yang dapat dipastikan lahirnya praktik-praktik riba. Memang yang terakhir ini menjadi bahan pemikiran. ${ }^{13}$

\footnotetext{
${ }^{12}$ Ibnu al-Qayyim, 'llam al-Muwaqqi'in, juz 3, hlm. 171.

${ }^{13}$ Al-Syathibi, Al-Muwafaqat, juz 2, hlm. 358.
} 
Dari berbagai pandangan tentang eksistensi dan fungsi dzara'i tersebut, maka yang kita perlukan untuk masa kini adalah mengembagkan instrumen-instrumennya serta ukuran-ukuran ilmiahnya sehingga dapat diketahui batasan-batasan $d z a r a ' i$ yang dapat menimbulkan akibat hukum, seperti batasan kualitatif; pasti, sering, terkadang atau langka, bahkan berdasarkan batasan kuantitatif berupa angka-angka prosentasi yang menggambarkan pengaruh suatu lingkungan atau tradisi sehingga pertimbangan hukum syara' dapat dipertanggungjawabkan secara ilmiah.

Obyek dan wilayah dzara'i merupakan hal perlu diperhatikan. Artinya, jika obyek dzara'i itu berkenaan dengan masalah muamalah atau adat, maka hukumnya kembali kepada hukum asal yaitu boleh, tak dilarang. Sedangkan bila menyangkut masalah ibadah dan munakahat, maka hukum asalnya adalah haram, tak dibolehkan. Dalam hal ini, metode istishhab yang dipegang atau berdasarkan prinsip umum syari'at yang menilai bolehnya segala tindakan hukum sebelum adanya ketentuan nash hukum, sebab sesuatu yang haram dalam syari'at Islam harus ditetapkan menurut dalil yang qathi sebagaimana ketegasan ayat 116 suratal-Nahl berikut:

"Dan janganlah kamu mengatakan terhadap apa yang disebut-sebut oleh lidahmu secara dusta "Ini halal dan ini haram", untuk mengada-adakan kebohongan terhadap Allah. ySesungguhnya orang-orang yang mengada-adakan kebohongan terhadap Allah Tiadalah beruntung".

Dalam hadits riwayat Muslim dari Nu'man bin Basyir dikatakan bahwa Rasul Saw bersabda :

"Sesungguhnya yang halal itu jelas, dan yang haram itu jelas, serta di antara keduanya ada yang tak jelas (musytabihat) yang tidak diketahui oleh banyak orang; barang siapa yang hati-hati dari yang syubhat, ia akan selamat dalam agamanya serta harga dirinya dan barang siapa yang melakukan hal itu, ia akan jatuh kepada yang diharamkan, ia laksana seorang pengembala di sekitar tanah larangan yang bisa saja melewati batasnya. Ingatlah, setiap pemilik ada perlindungan hukumnya. Perlindungan hukum Allah adalah segala larangan-Nya. Ingatlah, di dalam tubuh ada segumpal darah. Jika darah itu baik, baik pula tubuh itu, dan sebaliknya jika darah itu jelek, maka jelek pula tubuh. Ingatlah, segumpal darah itu adalah hati".

Pesan utama hadits tersebut menuntut bahwa hukum haram atau halal tak dapat ditetapkan kecuali berdasarkan dalil syara' yang bernilai pasti. Adapun hal-hal yang diduga kuat dapat menimbulkan pengaruhi negatif status hukum nikah dan ibadah, maka pendapat yang lebih dipilih adalah wajibnya menutup ekses tersebut (sadd aldzarâ'i) berdasarkan kaidah istishhab (menjalankan hukum asal yang telah berlaku), yaitu haram dan tidak boleh dilakukan. Dengan demikian, landasan hukum yang kita pegang dalam membedakan masalah dzara'i adalah keyakinan untuk memegang teguh prinsipprinsip umum hukum syara' yang mengatur segala praktik dan perbuatan sebelum adanya ketentuan pasti dari syara'. Yakni, selama hukum asal dalam segala sesuatu, 
muamalah dan adat adalah ibahah atau selama ada dalil yang pasti dari nilai-nilai universal Al-Qur'an dan Hadits, maka menolak atau menghilangkan hukum asal tersebut memerlukan dalil yang meyakinkan pula. Jika tidak ditemukan dalil pengubahnya, maka hukum semula yang tetap berlaku sesuai dengan kaidah al-ashlu baqou ma kana 'ala makana dan kaidah al-yaqin la yuzalu bi al-syak.

Dari keterangan tersebut, dapat kami simpulkan bahwa hukum syara' tentang dzara'i yang berkaitan dengan persoalan-persoalan kontemporer; harta, ekonomi, politik, budaya dan pendidikan yang berada di negeri-negeri muslim minoritas sangat tergantung pada tingkat pengaruhnya.Jika kita temukan praktek atau suatu kegiatan di bidang muamalah, adat dan kebiasaan lainnya yang diyakini berakibat haram, maka dapat dipastikan hukumnya haram berdasarkan kaidah yang menyatakan bahwa segala pengantar yang haram adalah haram pula hukumnya (muqaddimah al-haram haramun). Namun jika hal itu lebih mendekati atau terkadang menimbulkan keharaman, maka yang demikian boleh saja dilakukan dan tak sah adanya larangan langsung sebab akan bertentangan dengan kaidah asal kebolehan.

\section{Memegang kaidah fiqh yang bersifat umum.}

Penterapan kaidah-kaidah hukum (fiqh) yang bersifat umum telah teruji keampuhannya sejak lama dalam perjalan sejarah hukum Islam sehingga menjadi referensi hukum. Pengaplikasian kaidah-kaidah tersebut semakin terasa dibutuhkan untuk zaman sekarang terutama dalam menyelesaikan masalah aktual khususnya masalah muamalah, karena nash hukum syara' tentang masalah ini tidak bersifat detail, tetapi bersifat nash umum yang elastis dan luas, sebagai kemudahan Allah bahwa bidang muamalah itu akan terus berkembang dan berubah sehihingga hukum mampu mengatasi setiap yang baru pada setiap dan waktu. Kaidah-kaidah fiqh tersebut terformulasikan dalam lima kaidah besar atau prinsip umum (mabadi' kulliyah), yaitu: (1) al-umur bimaqâshidiha, (2) al-yaqin la yuzalu bi al-syakk, (3) al-masyaqah tajlîb al-taysîr, (4) la zharura wala zhirar, dan (5) al-'adah muhakkamah.

Dari kelima kaidah tersebut lahir ratusan kaidah cabang lainnya yang mencerminkan kedalaman dan ketajaman pemikiran hukum yang inovatif sebagaimana yang telah mentradisi pada abad pertama Hijriyah, sebelum terjangkitnya penyakit taqlid dan ketakutan-ketakutab berinovasi seperti yang terjadi di abad-abad akhir. Kelima kaidah tersebut dapat dipelajari secara tuntas dalam kitab yang spesifik karya Syekh Ahmad alZarqa dan Ali Ahmad al-Nadawi. Namun yang terpenting dalam konteks kekinian adalah tuntutan menghadirkan kaidah-kaidah yang relevan dalam menjawab setiap peristiwa hukum yang terjadi di wilayah muslim minoritas, seperti: (1) kaidah al-masyaqqah tajlib al-taysir, (2) kaidah al-dharurah tubih al-mahdhurat, dan (3) al-hajah qad tunazzalu manzilah al-dharurah, baik umum maupun khusus. 
Yang dimaksud dengan kaidah, al-masyaqqah (kesulitan), adalah kesulitan yang tidak dibiasakan dan dapat menghalangi ibadah serta mengganggu keberlangsungan hidup subyek hukum (mukallaf) sehingga situasi ini dapat menjadi alasan (sebab) yang dibenarkan syara' untuk tidak berlakunya hukum secara umum atau sebagian, baik yang berupa tuntutan berbuat maupun larangan sesuai dengan tingkat kesulitan yang baru dialaminya sehingga hukum mengalami perubahan sifatnya;mulai dari wajib, mandub atau mubah. Contoh, status hukum shaum bagi yang bepergian. Pada dasarnya shaum wajib bagi bagi orang Islam dalam situasi normal/biasa (Q.S. 2:183). Tetapi bagi orang Islam yang sedang menempuh perjalanan (musafir) kewajiban ini bisa menjadi sesuatu yang dianjurkan (mandub), bahkan menjadi sesuatu yang dibolehkan. Perubahan sifat hukum ini berdasarkan O.S. Al-Baqarah ayat 184, dan hadits Nabi Saw yang mengakui beberapa sahabat yang tetap berpuasa atau tidak selama dalam menempuh perjalanan.

Dalam situasi tertentu, terjadinya kesulitan yang di luar kebiasaan, bisa menjadi alasan hukum yang merubah sifat hukum sendiri; dari hukum wajib bisa menjadi haram. Misalnya, akibat shaum bagi orang sakit yang akan mengancam nyawanya. Dalam siatuasi seperti ini shaum diharamkan baginya menurut para ulama berdasarkan ayat 195 surat Al-Baqarah. Dari kasus ini, nampak hukum shaum berubah dari yang wajib menjadi haram. Dengan demikian, kesulitan di luar batas-batas kebiasaan dapat memperingan beban hukum (perintah atau larangan). Hal ini akan berlaku pula dalam menjawab peristiwa-peristiwa hukum yang terjadi di masyarakat muslim minoritas, khususnya dalam bidang perekonomian. Jelasnya, kaidah al-masyaqah ini erat kaitannya dengan kaidah al-dzra'l seperti telah dikemukakan. Singkatnya, dapat dikatakan bahwa kedua kaidah ini berkenaan dengan prinsip syari'at sendiri dari Al-Qur'an bahwa seseorang tak akan dibebani hukum kecuali menurut kemampuannya dan bahwa ia harus takwa kepada Allah menurut kemampuannya pula.

Metode penterapan dan penempatan hukum seperti itu merupakan dasar ilmiah yang wajib ditampilkan para ulama dalam memecahkan persoalan-persoalan yang menimpa muslim minoritas, yang berada di bawah sistem hukum lain. Pemikiran hukum semacam ini, oleh al-Syathibi, dinamakan dengan "Ijtihad Tahqiq al-Manath ". Menurutnya, ijtihad semacam ini akan terus berlangsung sampai kiamat, sebab ijtihad itu ada dua macam. Pertama, ijtihad yang tak mungkin berhenti sampai kiamat selama tuntutan keharusan hukum ada (asal taklif). Kedua, ijtihad yang dapat terhenti sebelum dunia berakhir. ljtihad macam pertama adalah ijtihad tahqiq al-manath yang keberadaannya telah diterima umat, yakni, segala ketetapan hukum yang bersumber dari syara' namun penempatannya terletak pada hasil pemikiran,...".

\section{Memperhatikan maksud dan akibat hukum.}

Setiap pemerhati hukum Islam akan mengetahui bahwa syariat Islam ditetapkan Allah untuk merealisir tujuan atau maksud luhurnya, baik yang terdapat dalam perintah- 
Nya maupun larangan-Nya. Hal ini berdasarkan penelaahan para ulama atas berbagai makna dan rahasia hukum yang ditetapkan Allah sehingga mereka menemukan konsep maqâshid al-syar'i atau al-maqâshid al-syarîah.

Al-Maqâshid al-Syarîah diformulasikan para ulama dalam pengertian segala makna dan hikmah yang diperhatikan oleh Al-Syari (Allah Pembuat syari'at) pada seluruh atau sebagian besar hukum-Nya, termasuk sifat-sifat syari'at dan sasaran-sasaranya serta hikmah-hikmah dalam beberapa macam hukum lainnya yang secara tidak langsung diperhatikan-Nya pula. ${ }^{14}$

Syekh 'Alal al-Fasy mendefinisikan maqâshid al-Syarî'ah dalam pengertian sasaran yang hendak dicapai syariat serta rahasia-rahasianya yang ditetapkan Syari pada setiap hukum. ${ }^{15}$ Simpelnya, Al-Risuny mendefinisikannya dalam pengertian segala sasaran hukum yang ditetapkan syari'at dan merealisasikannya untuk kemaslahatan hamba. ${ }^{16}$

Menurut Al-Syâthibî, seseorang akan sampai kepada puncak ijtihad bila telah memahami maqâshid al-syarîah secara sempurna. la mengatakan bahwa tingkat ijtihad akan diperoleh bagi yang telah memiliki dua syarat (sifat); pertama, memahami maksud syari'at secara sempurna, dan kedua, kemampuan menggali hukum (istinbath al-hukm) dengan memahami maksud-maksudnya. ${ }^{17}$

Langkah Al-Syâthibî tersebut diikuti oleh ulama modern dari Tunisia, Imam Muhammad Thahir Ibn Asyur dengan menambah beberapa penjelasan sekitar maksud hukum syara' dalam setiap masalah yang ada, termasuk tentang makna dan rahasia llahi yang terkandung dalam nash-nash syara', akibat-akibat hukum yang akan menimpa masyarakat, pertimbangan aspek manfaat dan madharat, dan perbedaan perbuatanperbuatan hukum yang sifatnya primer (dharuriyyat), sekunder (hajiyyat) dan tertier (tahsiniyyat). Prinsip inilah yang akan menjaga kita dalam memahami nash Kitab AlQur'an dan Sunnah Nabi yang bersifat umum secara benar sehingga tidak terjebak ke dalam metode lain yang membunuh syari'at sendiri. Prinsip ini pula yang dapat mengantarkan kita akan mampu mengamalkan kedua sumber syari'at sesuai dengan makna yang dikehendaki dan menempatkannya pada peristiwa hukum dengan tepat. Apabila para ulama sepakat bahwa setiap hukum syara' tersusun dari tiga unsur penting; (1) ilat hukum, sebagai sifat yang nampak dan terukur, (2) mashlahat, sebagai nilai manfaat dan madarat, dan (3) maqâshid, sebagai sasaran dari perbuatan hukum dalam menarik manfaat dan menolak mafsadat, maka disimpulkan bahwa yang disebut maqâshid al-syarîah adalah perwujudan atas sasaran-sasaran hukum itu sendiri. Dengan

\footnotetext{
${ }^{14}$ Syekh Muhamamdal-Thahir Ibn Asyur, Maqashid al-Syari'ah al-Islamiyyah (Al-Bashair li al-Intaj alIlmy, 1998), cet. Pertama, hlm. 171.

${ }^{15} \mathrm{Al}-\mathrm{Fasy}$, Maqashid al-Syari'ah al-Islamiyyah wa makarimuha (Dar al-Gharbi al-Islamy, 1993), cet. Ke v, hlm. 7

${ }^{16}$ Al-Risuny, Nadhariyah al-Maqashid inda Al-Syathiby (Riyadh: Al-Dar al-'Alamiyyah li al-Kitab alIslamy, 1992), cet. Kedua, hlm. 7 .

${ }^{17}$ Al-Syathiby, Al-Muwafaqat fi Ushul al-Syari'ah (Riyadh: Al-Dar al-Alamiyyah,1992), juz IV, hlm. 106.
} 
demikian, setiap kegiatan hidup menjadi pertimbangan syara' bila mengandung satu di antara dua hal, yaitu; mendatangkan manfaat atau menolak mafsadat.

Memperhatikan maqâshid al-syarîah sangat penting, sebab segala nash syara' (teks Al-Qur'an dan Sunnah Nabi) tak cukup untuk menjelaskan setiap peristiwa hukum dalam ruang dan waktu tertentu kecuali dengan menempuh dua langkah; pertama, mengungkap dan menjelaskan makna-makna hukum secara teoritis, dan kedua, menerapkan makna-makna hukum tersebut dalam bentuk nilai-nilai manfaat dan mafsadatnya.

Memegang teguh konsep maqâshid al-syarî'ah, para ulama akan sampai pada kesimpulan bahwa kemaslahatan yang diinginkan syara' ada tiga macam, yaitu:

Pertama, maslahah dharuriyah, yaitu kemaslahatan yang sangat dibutuhkan oleh kehidupan manusia, baik yang bersifat diniyyah (spritual keagamaan) maupun duniawiyyah (keduniawian), sebab bila kedua kebutuhan ini tak terpenuhi maka tatanan kehidupan akan hancur, misalnya, terjadinya keruksakan dan kekacauan pada semua sendi kehidupan. Menurut mayoritas ulama metodologi hukum Islam (ushuliyyin), kemaslahan jenis pertama ini bertujuan dalam memelihara lima hal; nyawa, agama, keturunan (nasal), akal dan harta. ${ }^{18}$

Kedua, maslahah hajiyyah, yaitu kemaslahatan yang dibutuhkan manusia untuk kemudahan hidupnya. Tidak terpenuhinya kemaslahatan ini tidak mengakibat hancurnya tatanan kehidupan tetapi hanya menimbulkan kesempitan dan kesulitan.

Ketiga, maslahah tahsiniyyah, yaitu kemaslahatan yang menjadi tuntutan harga diri (muru'ah) yang berupa kebiasaan yang baik dan kemuliaan akhlak. Tak terpenuhinya kemaslahatan ini tetap tidak akan menghancurkankan tatanan kehidupan. Kemaslahan semacam ini akan terus berkembang seiring dengan tuntutan ruang dan waktu.

\section{Penutup}

Berbagai persoalan hukum baru yang secara langsung tidak tercantum dalam teks-teks hukum yang diwahyukan, menuntut model ijtihad baru yang berlandaskan teori qiyas, yang melewati teori-teori parsial. Model jtihad ini hendaknya berpijak pada tiga hal pertama, memahami kasus baru secara umum; kedua, mengolahnya dalam bentuk konsep yang lebih detail; dan ketiga, menempatkannya dalam bentuk konsep tersendiri untuk kehidupan nyata. Ketiga hal tersebut tercermin dalam; (1) prinsip-prinsip umum yang terkandung dalam nash dan kaidah umum sehingga dapat dinilai sebagai kaidah yang lentur (muraunah) yang mampu mengakomodasi setiap masalah baru; (2)

\footnotetext{
${ }^{18}$ Al-Syathiby berkata: "Ketahuilah, sesungguhnya taklif-taklif (kewajiban-kewajiban) syara' kembali kepada pemeliharaan maksud-maksudnya bagi makhluk, yang tidak lebih dari tiga hal, yaitu; dharuriyyah, hajiyyah, dan tahsiniyyah. Kemaslahatan dharuriyyah adalah kemaslahatan yang mesti ada bagi tegaknya kemaslahatan agama dan dunia, dan jika tidak terpunuhi akan menghancurkan kehidupan., yaitu; memelihara agama, nyawa, keturunan, harta dan akal (Al-Muwafaqat, juz II, hlm. 324-325.
} 
tujuan dan prioritas (tarjih) yang disimpulkan dari nash umum, dan (3) memperhatikan akibat perbuatan hukum sehingga dapat dilakukan atau tidak.

Singkatnya, mengatasi masalah-masalah yang dialami masyarakat muslim minoritas harus berpijak pada metode ijtihad yang benar sebagaimana tercermin dalam tiga dasar. Pertama, memegang teguh kaidah al-dzarâi (fath atau sadd) ketika sulit menjelaskan hukum dalam persoalan politik, sosial, ekonomi dan pendidikan. Kedua, memegang kaidah-kaidah kulli ketika ingin menjelaskan hukum untuk masalah yang berbeda-beda, khususnya kaidah al-masyaqqah tajlïb al-taysîr, al-dharûrat tubîh al-mahdhûrât, al-hâjjah tunazzalu manzilah al-dharûrat 'ammah aw khashshah, idza dhâqa alamru ittasa'a dan kaidah-kaidah penting lainnya, karena adanya hukum yang bersifat umum jangan sampai menghentikan upaya ijtihad, misalnya, memperhatikan situasi dan kondisi setiap subyek hukum (mukallaf) di mana suatu hukum akan diterapkan sehingga perlunya ijtihad tahqiiq al-manath secara khusus. Ketiga, memperhatikan maksud hukum dan penterapannya pada setiap kasus hukum yang dialami muslim minoritas yang berbeda-beda sehingga teks-teks hukum dari Al-Qur'an dan Sunnah Nabi tidak gunakan langsung, tetapi melalui kajian manfaat dan mafsadat termasuk akibat-akibatnya sehingga seseorang dapat melakukan suatu perbuatan atau sebaliknya. Bagian terakhir inilah yang dinamakan dengan maqâshid al-syarîah, yaitu setiap sasaran dan rahasia setiap hukum yang ditetapkan oleh Syari (Allah Pembuat hukum syara'). Bagian ini wajib dipegang untuk menjelaskan tujuan hukum yang berada di belakang teks hukum dan implikasinya terhadap perbuatan.

\section{Daftar Pustaka}

Al-Fasy. 1993. Maqashid Al-Syari'ah Al-Islamiyyah Wa Makarimuha. t.t. Dar al-Gharbi alIslamy. cet. Ke v

Al-Razy. 1992. Al-Mahshul fi Ilmi Al-Ushul. Beirut: Muassasah al-Risalah

Al-Risuny. 1992. Nadhariyah al-Maqashid inda Al-Syathiby. Riyadh: Al-Dar al-'Alamiyyah li al-Kitab al-Islamy.

Al-Syathiby. 1992. Al-Muwafaqat fi Ushul al-Syari'ah. Riyadh: Al-Dar al-Alamiyyah.

Al-Syaukani. 1992. Irsyad al-Fuhul. Mesir: Dar al-Kutub. juz 2, cet. 1

Asy-Syatibi, Abu Ishaq. t.th. Al-Muwâfaqât fí Ushûl al-Ahkâm. Ta'lîq [Komen-tar] oleh Muhammad Al-Hidhr Husain. Juz IV. Beirut: Darul Fikr.

Asyur, Syekh Muhamamdal-Thahir Ibn. 1998. Maqashid al-Syari'ah al-Islamiyyah. t.t. AlBashair li al-Intaj al-Ilmy. cet. Pertama,

Bagdadi, Qadli Abdul Wahab al-.t.th. Al-Isyraf ala masa'il al-Khilaf, juz. 1,(t.tp.:t.pn,)

Fasy, Imam Alal, al-.1993. Mendefinisikannya maqashid al-syari'ah dalam pengertian sasaran dan rahasia hukum yang ditetapkan Allah. Beirut: Dar al-Gharbi.

Hasanah, Umar Ubaid. 199o. Tammulat fí al-waqi' al-Islamy. Beirut: Al-Maktab Al-Islami, cet. Pertama 
Husain, Muhammad al-Hadhar al. 1971. Al-Syari'at al-Islamiyyah shâlih likulli zamân wa makân (t.tp:t.p,)

Jauziyah, Ibnu al-Qayyim, al-. t.th. (Pent. Kathur Suhardi), Zadul-Maád Bekal Menuju Akhirat Juz 3, Jakarta : Pustaka Azam

Sanu, Qutub al-Mushthafa. 2008. Al-ljtihâd wa Mustajiddat al'-Ashr, makalah pada Seminar Internasional (Libiya: World Islamic Call Society, 27-30 Oktober 2008) 
34 | Asy-Syari'ah Vol. 20 No. 1, Agustus 2018 